\title{
Evaluation of Cotton Germ Plasm for Resistance to the Whitefly and Cotton Leaf Crumple (CLCr) Disease and Etiology of CLCr in California's Imperial Valley
}

\author{
Y.-S. Seo and Y.-C. Zhou, Department of Plant Pathology, University of California, Davis 95616; T. A. Turini, Uni- \\ versity of California Cooperative Extension, UC Desert Research \& Extension Center, 1050 E. Holton Road, Holt- \\ ville 92250; C. G. Cook, Syngenta Seeds Inc., 356 Hosek Road, Victoria, TX 77905; R. L. Gilbertson, Department \\ of Plant Pathology, University of California, Davis 95616; and E. T. Natwick, University of California Cooperative \\ Extension, UC Desert Research \& Extension Center, 1050 E. Holton Road, Holtville 92250
}

\begin{abstract}
Seo, Y.-S., Zhou, Y.-C., Turini, T. A., Cook, C. G., Gilbertson, R. L., and Natwick, E. T. 2006. Evaluation of cotton germ plasm for resistance to the whitefly and cotton leaf crumple (CLCr) disease and etiology of CLCr in California's Imperial Valley. Plant Dis. 90:877-884.

Cotton (Gossypium hirsutum) entries were evaluated for resistance to the whitefly (Bemisia tabaci biotype B) and cotton leaf crumple (CLCr) disease during the 1999 to 2001 growing seasons in the Imperial Valley of California. Entries were evaluated for densities of whitefly adults and nymphs, and for CLCr, by visual rating and squash/dot blot hybridization analyses. Differences in whitefly densities were detected among entries, but none were highly resistant, nor was there any correlation with CLCr disease severity. Entries AP 4103 and AP 6101 had relatively low whitefly densities and were highly susceptible (high CLCr disease severity ratings and viral titers), whereas NK 2387C and DPX 1883 also had low whitefly densities but were highly resistant (no symptoms or detectable viral titers). Other entries showed moderate CLCr resistance, which was independent of whitefly density. Geminivirus DNA-A and DNA-B components were consistently detected in cotton leaves with CLCr symptoms by polymerase chain reaction (PCR) with degenerate begomovirus primers, and full-length DNA-A and DNA-B clones were obtained. Cotton seedlings inoculated with these cloned DNAs by particle bombardment developed CLCr symptoms, and progeny virus was whitefly-transmissible. Sequence analysis revealed that these clones comprised the genome of a California isolate of the bipartite begomovirus Cotton leaf crumple virus (CLCrV-CA). Thus, CLCr disease in the Imperial Valley is caused by CLCrV-CA, and cotton entries with high levels of resistance were identified.
\end{abstract}

The whitefly, Bemisia tabaci biotype B (=Bemisia argentifolii Bell. \& Perring; 2), was first identified in 1990 in the Imperial Valley of California (32). It has since emerged as a serious pest of cotton (Gossypium hirsutum L.) and other crops in the southwestern United States (28,34). In addition to causing direct damage to cotton (reduced yields or contamination of lint with honeydew and sooty molds, i.e., sticky cotton), this whitefly also vectors several economically important viral diseases (4), including cotton leaf crumple (CLCr) $(7,12)$. Symptoms of CLCr include blistering, crumpling, and mottling of leaves and enations on flowers $(12,14)$. Infected plants may be stunted, and numbers of bolls and seed-cotton yields are reduced $(1,8,9,36)$. Over the past 50 years, various lines of evidence have implicated a geminivirus, Cotton leaf crumple virus (CLCrV; genus Begomovirus, family Geminiviridae), as the causal agent of CLCr

Corresponding author: Robert L. Gilbertson

E-mail: rlgilbertson@ucdavis.edu

Accepted for publication 2 February 2006.

DOI: 10.1094/PD-90-0877

(C) 2006 The American Phytopathological Society including: transmission by $B$. tabaci $(7,24)$, observation of diagnostic viral inclusion bodies (35), purification of geminate particles (6), and detection and characterization of begomovirus DNA-A and DNA-B components $(25,29)$. Conclusive evidence was recently provided by Idris and Brown (23), who demonstrated that the cloned DNA-A and DNA-B components of a CLCrV isolate from Sonora, Mexico (CLCrV-SON) induced CLCr symptoms when biolistically delivered into cotton seedlings.

A CLCr-like disease was first mentioned by Cook in 1924 (10), but the disease was first described from the Coachella and Imperial Valleys of California in the late 1940 s to early 1950 s (12). By the late 1950 s to early 1960 s, economic losses due to $\mathrm{CLCr}$ were being reported in cotton production in the Coachella and Imperial valleys and the Yuma Valley of Arizona $(1,12,24,36)$. In the Yuma Valley, yield losses of up to $85 \%$ were experienced in some Acala cotton fields (36). A number of factors were subsequently identified that influenced disease severity and yield loss. Plants infected at a young age (e.g., twoto eight-leaf stage) develop more severe symptoms, including stunted growth, and experience higher yield losses compared with plants infected later (e.g., after flow- ering), which develop disease symptoms in new growth but are usually not stunted $(5,8,9,12-14,36)$. Second, increased CLCr incidence was associated with the practice of growing perennial or ratoon (stubbed) cotton (4). Here, severely diseased sprouts, emerging from infected ratoon cotton the following season, serve as an inoculum source for young plants in direct-seeded fields. This led to the banning of ratoon cotton and the elimination of this important early-season inoculum source (8).

In the early 1980 s, an increased incidence of CLCr in desert cotton was associated with outbreaks of B. tabaci (13). Sporadic CLCr outbreaks continued, particularly when whitefly populations were high early in the season and sources of inoculum were present, i.e., cotton plants surviving from the previous season and reservoir hosts such as cheeseweed (Malva parviflora L.) (7,13). Thus, the massive outbreaks of B. tabaci biotype B in the early to mid-1990s (34) raised concerns about an increase in the economic importance of whitefly-transmitted geminiviruses (20).

Insecticides can provide temporary management of whiteflies $(27,34)$, but do not provide effective control of CLCr. A long-term solution that offers economical and environmental advantages is the development of CLCr-resistant cultivars (29). Wilson et al. (38) reported that cv. Cedix was a promising source of CLCr resistance. The objectives of this study were to: (i) evaluate cotton entries, including a number with cv. Cedix parentage, for resistance to B. tabaci and CLCr disease, (ii) determine the etiology of CLCr in the Imperial Valley, and (iii) develop molecular tools to facilitate virus detection and resistance breeding.

\section{MATERIALS AND METHODS}

Field plots. Field studies were conducted during the 1999 to 2001 growing seasons at the University of California Desert Research and Extension Center in the Imperial Valley, CA. The experimental design was a randomized complete block with four replicates. Individual plots measured $15 \mathrm{~m}$ long and $4 \mathrm{~m}$ wide. Rows were $1 \mathrm{~m}$ apart. Seeds of the cotton entries were sown and irrigated in March of each year. Entries evaluated each year of the 
study were: Texas 121 (South Texas Planting Seed Assoc.), AP 4103 and AP 6101 (AgriPro Seeds), Stoneville 474 (Stoneville Pedigreed Seed Company), and NK 2387C and NK 2108SS (Syngenta Seeds, Inc.; previously DG 2387 and DG 2108, respectively, United Agri Products). Additional entries evaluated were: in 1999, DG 2165 and DG 2383 (United Agri Products); in 2000, NK 2165C (previously DG 2165, United Agri Products), NKX C429-93-2ct, NKX 2907, and NKX 2207 (Syngenta Seeds, Inc.); and in 2001, DPX 1883 (Delta Pine and Land Company).

Adult whitefly densities were determined weekly from 10 plants in each plot using the leaf turn method (26). Nymphs were counted weekly on a $1.65-\mathrm{cm}^{2}$ leaf disk taken from each of 10 randomly selected fifth-node leaves collected from each plot during June through August. Whole plant CLCr disease severity ratings (DSRs) were taken in each plot on 23, 27, and 30 August and 6 September in 1999; 14, 23, and 28 August in 2000; and 9 and 24 July, 8 and 21 August, and 5 and 18 September in 2001. The rating scale used was: $1=$ leaves smooth, few if any bumps or blisters; $2=$ leaves with some obvious blisters and crumpling, but on $<50 \%$ of the leaf surface; $3=$ leaves with obvious crumpling, blisters, and vein clearing on $>50 \%$ of the leaf surface, but with little or no epinasty; and $4=$ leaves with severe crumpling, blisters, epinasty, and distortion. Seed cotton was hand-picked from two 4-m sections of rows in each plot in October of each year, and weights were recorded. Seasonal whitefly density, CLCr DSRs, and yield data were analyzed using ANOVA, and Student-Neuman-Keul's multiple range test was employed for mean separations (MSTAT-C 1989).

CLCr leaf ratings and squash and dot blot hybridization analyses. In 1999, 10 representative leaves from each entry were collected and visually rated for CLCr according to the rating scale described above. Leaf disks from these leaves were then squashed onto duplicate nylon membranes (Nytran) and hybridized with two DNA probes: (i) a general probe for whiteflytransmitted geminiviruses under conditions of low stringency, and (ii) a CLCr-specific probe (a cloned 1.5-kb begomovirus DNA$\mathrm{B}$ fragment from cotton leaves with CLCr symptoms) under conditions of high stringency (19). The rating scale used to assess the hybridization results was: $1=$ no hybridization signal (no infection); 2 = faint and uneven signal (questionable infection); $3=$ obvious and generally uniform signal (infected plant; low to moderate levels of viral DNA); 4 = dark gray uniform signal (infected plant; moderate to high level of viral DNA); and $5=$ black uniform signal (infected plant; very high level of virus).

In 2000 and 2001, 10 representative leaves from each entry were collected and visually rated for CLCr as described above. These leaves were then used for dot blot hybridization analysis. Here, total genomic DNA was extracted from $0.1 \mathrm{~g}$ of leaf tissue with a modified CTAB method (18), and $2 \mu \mathrm{l}$ of DNA extract from each leaf was applied onto a nylon membrane. The membranes were hybridized with a CLCr probe (a cloned 1.1-kb begomovirus DNA-A fragment from cotton leaves with CLCr symptoms) under high stringency conditions. The intensity of the resulting hybridization signals was determined with a phosphoimaging system (Storm 840, Amersham Biosciences, Piscataway, NJ).

DNA extraction, polymerase chain reaction (PCR), and cloning and sequencing of PCR-amplified DNA fragments. DNA extracts were prepared from cotton leaves using either the Dellaporta method (11) or the modified CTAB method (18). These extracts were used in the PCR with degenerate primers for begomovirus DNAA (pAL1v1978 and pAR1c496) and DNAB (pBL1v2040 and pBV1c970) components as previously described $(16,33)$. PCR-amplified DNA fragments were cloned and sequenced as previously described $(17,33)$. Sequences were analyzed using the software of the Genetics Computer Group (Version 10; University of Wisconsin, Madison), and the BLAST program was used to compare sequences with those in the GenBank.

Generating full-length geminivirus clones and particle bombardment inoculation. Full-length geminivirus DNA-A and DNA-B clones were generated using PCR and the overlapping primer method (31). The following overlapping primers with the indicated restriction sites were designed from sequences of PCRamplified DNA-A and DNA-B fragments: DNA-A, CLCrAVS1 (5'-TCAGGTAAGCTTTGTGGAGATA-3') and CLCrACS1 (5'-CACAAAGCTTACCTGAACTTCC-3') with a HindIII site; and DNA-B, CLCrBVS1 (5'-CGGAAACTGCAGAACGATCTCA-3') and CLCrBCS1 (5'-CGTTCTGCAGTTTCCGTCAACG-3') with a PstI site. Recombinant plasmids having the expected-size insert $(\sim 2.6 \mathrm{~kb})$ were identified by restriction enzyme analysis.

Infectivity was determined by particle bombardment of excised linear doublestranded monomers into hypocotyls of 48h-old cotton and common bean seedlings as previously described (30). Control seedlings were bombarded with gold particles only. Seedlings were planted in soil and maintained in a growth chamber. Symptom development was recorded 10 to 21 days postbombardment (dpb). In selected plants, the presence of begomovirus DNA-A and DNA-B components was confirmed by PCR.

Whitefly transmission. To assess whitefly transmission of progeny virus derived from infectious cloned DNAs, cotton plants showing CLCr symptoms were exposed to $\sim 500$ non-viruliferous whiteflies for an acquisition access period (AAP) of $24 \mathrm{~h}$. Approximately 50 whiteflies were then transferred onto cotton seedlings (two-true-leaf stage) for an inoculation access period of $48 \mathrm{~h}$, after which plants were sprayed with insecticide (resmethrin) to kill the whiteflies. Controls were whiteflies that were fed on cotton plants infected with a whitefly-transmissible field isolate of CLCrV from the San Joaquin Valley of California, and whiteflies fed on uninfected (healthy) cotton plants.

Sequence and phylogenetic analysis. DNA sequencing of the full-length infectious DNA-A (in plasmid pCLCrVA1-40) and DNA-B (in plasmid pCLCrVB-8) clones was performed using the primerwalking method and ABI PRISM Dye Terminator Cycle Sequencing. Sequencing reactions were fractionated in 5\% Long Ranger gels, and data were collected with ABI Prism Á Sequencing software (Perkin-Elmer Cetus, Foster City, CA). DNA sequence comparisons were performed as described above. The AC1 and $\mathrm{BC} 1$ nucleotide (nt) sequences from these cloned DNAs and other begomoviruses were aligned with PILEUP, and phylogenetic analyses were performed with Phylogenetic Analysis Using Parsimony (PAUP) Version 4.0 b10 (Sinauer Associates Inc., Sunderland, MA). Optimum trees and branch strengths were determined as previously described (15).

\section{RESULTS}

Whitefly densities. In 1999, Stoneville 474 had the greatest number of adults $\left(22.1 / \mathrm{cm}^{2}\right)$, whereas all other entries had similar and significantly lower densities (Table 1). Stoneville 474 also had the greatest number of whitefly nymphs $\left(15.1 / \mathrm{cm}^{2}\right)$, whereas $\mathrm{NK} 2165 \mathrm{C}$ had the lowest number $\left(3.5 / \mathrm{cm}^{2}\right)$. In 2000 , NKX C429-93-2ct (not evaluated in 1999) and Stoneville 474 had the greatest number of adults $\left(28.6 / \mathrm{cm}^{2}\right.$ and $16.1 / \mathrm{cm}^{2}$, respectively), whereas NK $2387 \mathrm{C}$ had the lowest number $\left(8.7 / \mathrm{cm}^{2}\right)$. NKX C429-93-2ct and Stoneville 474 also had the greatest number of nymphs $\left(25.5 / \mathrm{cm}^{2}\right.$ and $19.4 / \mathrm{cm}^{2}$, respectively), whereas all other entries had similar and significantly lower densities (Table 1). In 2001, Stoneville 474 again had the greatest number of adults $\left(15.6 / \mathrm{cm}^{2}\right)$ (note that NKX C429-93-2ct was not evaluated in 2001), and NK 2387C had the lowest number $\left(7.7 / \mathrm{cm}^{2}\right)$. Stoneville 474 and NK 2108SS had the greatest number of nymphs $\left(12.8 / \mathrm{cm}^{2}\right.$ and $7.1 / \mathrm{cm}^{2}$, respectively), whereas all other entries had similar and significantly lower densities (Table 1).

Whole plant CLCr disease ratings (field). In 1999, AP 4103 had the highest CLCr DSR (3.6), and leaves showed severe CLCr symptoms, including leaf crumpling, blisters, deformation, and epinasty. AP 6101 and Stoneville 474 also 
showed obvious CLCr symptoms and had DSRs of 3.0 and 2.5, respectively. Texas 121 had moderate symptoms and a DSR of 2.1. Four entries showed few or no symptoms and had significantly lower DSRs: NK 2108SS, NK 2165C, DG 2383, and NK 2387C (Table 2). In 2000, AP 6101 and AP 4103 had the highest DSRs (3.5 and 3.1, respectively), whereas NK 2108SS and NKX C429-93-2ct showed obvious CLCr symptoms and had relatively high DSRs (2.6 and 2.9, respectively). Texas 121 developed moderate symptoms and had a DSR of 2.3. Four entries developed mild symptoms and had significantly lower DSRs: NK 2165C, NKX 2207, NKX 2907, and Stoneville 474 (Table 2). NK 2387C had no obvious symptoms and the lowest DSR (1.0). In 2001, AP 4103 and AP 6101 again had the highest DSRs (3.2 and 3.0, respectively). NK 2108SS, Texas 121, and Stoneville 474 had mild to moderate disease symptoms and DSRs ranging from 2.1 to 2.4 (Table 2). Entries DPX 1883 and NK $2387 \mathrm{C}$ had no obvious symptoms and significantly lower DSRs, 1.1 and 1.0, respectively.

Cotton seed and lint yields. In 1999, AP 6101 had the highest cotton seed yield $(3,074.8 \mathrm{~kg} / \mathrm{ha})$, which was significantly greater than yields of all other entries except AP $4103(2,751.1 \mathrm{~kg} / \mathrm{ha})$ and DG 2383 (2,579.4 kg/ha) (Table 3). Stoneville $474 \mathrm{had}$ the lowest yield $(1,401.0 \mathrm{~kg} / \mathrm{ha})$. In 2000, cultivars AP 6101 and AP 4103 again had the highest seed cotton yields $(3,193.8 \mathrm{~kg} / \mathrm{ha}$ and $3,162.1 \mathrm{~kg} / \mathrm{ha}$, respectively); these were significantly greater than all other entries except NK 2387C $(2,657.7 \mathrm{~kg} / \mathrm{ha})$, Stoneville $474(2,270.0$ $\mathrm{kg} / \mathrm{ha})$, and NK 2108SS (2,236.4 kg/ha). NKX 2907 had the lowest seed cotton yield $(1,909.6 \mathrm{~kg} / \mathrm{ha})$. In 2001 , there were no significant differences among entries, and cotton seed yields ranged from 2,527.0 $\mathrm{kg} / \mathrm{ha}$ for AP 6101 to $1,893.5 \mathrm{~kg} / \mathrm{ha}$ for Stoneville 474 (Table 3).

Squash and dot blot hybridization results. The 1999 CLCr leaf DSRs and squash blot results are presented in Table 4. Squash blot hybridization with the general geminivirus probe resulted in nonspecific signal from negative controls (uninfected cotton) and relatively weak signals from leaves with obvious CLCr symptoms. Less nonspecific hybridization occurred with the CLCr probe, but signals were still relatively low. These results suggest that cotton tissues provide relatively high background in this test, and that the virus titer may be relatively low, even in leaves with obvious symptoms. Nonetheless, entries having the highest CLCr DSRs (AP 4103 and AP 6101) had the highest hybridization ratings, whereas those that did not show symptoms (NK 2387C and NK 2165C) had the lowest (Table 4).

A dot blot hybridization test was used in 2000 and 2001 to reduce levels of background and increase hybridization signals.
Control experiments revealed little or no background for DNA extracts from uninfected cotton leaves (dot blot signal of 1.5), and strong signals (50.0) from $2 \mu \mathrm{l}$ of an extract prepared from symptomatic cotton leaves confirmed to be begomovirus-infected by PCR with degenerate primers (data not shown). The $2000 \mathrm{CLCr}$ leaf DSRs and dot blot hybridization results are presented in Table 4. AP 4103 and AP 6101 had the highest DSRs (3.6 and
3.0, respectively) and dot blot signals (36.5 and 24.2, respectively). Entries with mild to moderate symptoms and lower DSRs (1.8 to 2.2) generally had lower dot blot ratings, although there were some exceptions (Table 4). NK 2387C and Stoneville 474 had the lowest DSRs (1.0 and 1.2, respectively) and dot blot signals (1.8 and 6.2 , respectively). In PCR tests conducted in 2000, begomovirus DNA was not detected in leaves of NK 2387C plants,

Table 1. Densities of Bemisia tabaci adults and nymphs on leaves of cotton entries during the 1999 to 2001 growing seasons in the Imperial Valley of California

\begin{tabular}{|c|c|c|c|c|c|c|}
\hline \multirow[b]{2}{*}{ Cotton entry } & \multicolumn{3}{|c|}{ Adults/leaf } & \multicolumn{3}{|c|}{ Nymphs/cm ${ }^{2}$ leaf disk } \\
\hline & 1999 & $2000^{z}$ & 2001 & $1999^{z}$ & 2000 & 2001 \\
\hline NKX C429-93-2ct & & $28.6 \mathrm{a}$ & & & $25.5 \mathrm{a}$ & \\
\hline Stoneville 474 & $22.1 \mathrm{a}$ & $16.1 \mathrm{~b}$ & $15.6 \mathrm{a}$ & $15.1 \mathrm{a}$ & $19.4 \mathrm{~b}$ & $12.8 \mathrm{a}$ \\
\hline NK 2108SS (DG 2108) & $12.5 \mathrm{~b}$ & $12.0 \mathrm{bc}$ & $10.0 \mathrm{bc}$ & $8.7 \mathrm{~b}$ & $8.8 \mathrm{c}$ & $7.1 \mathrm{~b}$ \\
\hline NKX 2207 & & $11.6 \mathrm{bc}$ & & & $8.7 \mathrm{c}$ & \\
\hline AP 6101 & $11.2 \mathrm{~b}$ & $11.4 \mathrm{bc}$ & $9.0 \mathrm{~cd}$ & $5.1 \mathrm{cde}$ & $5.2 \mathrm{c}$ & $4.3 \mathrm{c}$ \\
\hline AP 4103 & $10.9 \mathrm{~b}$ & $10.8 \mathrm{bc}$ & $10.0 \mathrm{bc}$ & $4.9 \mathrm{cde}$ & $6.1 \mathrm{c}$ & $4.3 \mathrm{c}$ \\
\hline NK 2387C (DG 2387) & $10.8 \mathrm{~b}$ & $8.7 \mathrm{c}$ & $7.7 \mathrm{~cd}$ & $5.4 \mathrm{c}$ & $6.1 \mathrm{c}$ & $3.3 \mathrm{c}$ \\
\hline Texas 121 & $10.6 \mathrm{~b}$ & $9.8 \mathrm{bc}$ & $8.3 \mathrm{~cd}$ & $5.3 \mathrm{~cd}$ & $7.4 \mathrm{c}$ & $2.5 \mathrm{c}$ \\
\hline NKX 2907 & & $9.8 \mathrm{bc}$ & $\ldots$ & $\ldots$ & $7.7 \mathrm{c}$ & $\ldots$ \\
\hline NK 2165C (DG 2165) & $10.2 \mathrm{~b}$ & $9.1 \mathrm{bc}$ & $\ldots$ & $3.5 \mathrm{f}$ & $5.3 \mathrm{c}$ & $\ldots$ \\
\hline DG 2383 & $9.1 \mathrm{~b}$ & $\ldots$ & $\ldots$ & $3.8 \mathrm{ef}$ & $\ldots$ & $\ldots$ \\
\hline DPX 1883 & $\ldots$ & $\ldots$ & $11.6 \mathrm{~b}$ & $\ldots$ & $\ldots$ & $4.4 \mathrm{c}$ \\
\hline
\end{tabular}

${ }^{\mathrm{z}} \log$ transformed data used for analysis; reverse transformed means reported. Mean separations within columns by Student-Newman-Keul's multiple range test, $P \leq 0.05$.

Table 2. Mean cotton leaf crumple disease ratings ${ }^{y}$ determined for cotton entries during the 1999 to 2001 growing seasons in the Imperial Valley of California

\begin{tabular}{|c|c|c|c|}
\hline \multirow[b]{2}{*}{ Cotton entry } & \multicolumn{3}{|c|}{ Seasonal means ${ }^{\mathrm{z}}$} \\
\hline & 1999 & 2000 & 2001 \\
\hline AP 4103 & $3.6 \mathrm{a}$ & $3.1 \mathrm{ab}$ & $3.2 \mathrm{a}$ \\
\hline AP 6101 & $3.0 \mathrm{~b}$ & $3.5 \mathrm{a}$ & $3.0 \mathrm{a}$ \\
\hline NK 2108SS (DG 2108) & $1.5 \mathrm{e}$ & $2.9 \mathrm{bc}$ & $2.4 \mathrm{~b}$ \\
\hline Texas 121 & $2.1 \mathrm{~d}$ & $2.3 \mathrm{~cd}$ & $2.3 \mathrm{~b}$ \\
\hline Stoneville 474 & $2.5 \mathrm{c}$ & $1.6 \mathrm{de}$ & $2.1 \mathrm{~b}$ \\
\hline NKX C429-93-2ct & $\ldots$ & $2.6 \mathrm{bc}$ & $\ldots$ \\
\hline NKX 2207 & $\ldots$ & $1.7 \mathrm{~d}$ & $\ldots$ \\
\hline NKX 2907 & $\ldots$ & $1.6 \mathrm{de}$ & $\ldots$ \\
\hline NK 2165C (DG 2165) & $1.4 \mathrm{e}$ & $1.9 \mathrm{~d}$ & $\ldots$ \\
\hline DG 2383 & $1.1 \mathrm{e}$ & $\ldots$ & $\ldots$ \\
\hline DPX 1883 & $\ldots$ & $\ldots$ & $1.1 \mathrm{c}$ \\
\hline NK 2387C (DG 2387) & $1.1 \mathrm{e}$ & $1.0 \mathrm{e}$ & $1.0 \mathrm{c}$ \\
\hline
\end{tabular}

${ }^{\mathrm{y}}$ The rating scale used was: 1 = leaves smooth, few if any bumps or blisters; $2=$ leaves with some obvious blisters and crumpling, but on $<50 \%$ of the leaf surface; $3=$ leaves with obvious crumpling, blisters and vein clearing on $>50 \%$ of the leaf surface, but with little or no epinasty; and $4=$ leaves with severe crumpling, blisters, epinasty, and distortion.

${ }^{\mathrm{z}}$ Mean separations within columns by Student-Newman-Keul's multiple range test, $P \leq 0.05$.

Table 3. Yield of seed cotton and lint turnout percentages

\begin{tabular}{lccc}
\hline & \multicolumn{3}{c}{ kg line/ha } \\
\cline { 2 - 4 } Variety & $\mathbf{1 9 9 9}$ & $\mathbf{2 0 0 0}$ & $\mathbf{2 0 0 1}$ \\
\hline DPX 1883 & $\ldots$ & $\ldots$ & $2,527.0 \mathrm{a}$ \\
AP 6101 & $3,074.8 \mathrm{a}$ & $3,193.8 \mathrm{a}$ & $2,206.0 \mathrm{a}$ \\
AP 4103 & $2,751.1 \mathrm{ab}$ & $3,162.1 \mathrm{a}$ & $2,341.0 \mathrm{a}$ \\
DG 2383 & $2,579.4 \mathrm{ab}$ & $\ldots$ & $\ldots$ \\
NK 2165C (DG 2165) & $2,257.8 \mathrm{bc}$ & $2,109.3 \mathrm{bc}$ & $\ldots$ \\
Texas 121 & $2,242.4 \mathrm{bc}$ & $2,129.0 \mathrm{bc}$ & $2,275.0 \mathrm{a}$ \\
NK 2387C (DG 2387) & $2,129.4 \mathrm{bc}$ & $2,657.7 \mathrm{ab}$ & $2,308.0 \mathrm{a}$ \\
NK 2108SS (DG 2108) & $1,811.5 \mathrm{~cd}$ & $2,236.4 \mathrm{abc}$ & $2,003.0 \mathrm{a}$ \\
Stoneville 474 & $1,401.0 \mathrm{~d}$ & $2,270.0 \mathrm{abc}$ & $1,893.5 \mathrm{a}$ \\
NKX C429-93-2ct & $\ldots$ & $2,030.9 \mathrm{bc}$ & $\ldots$ \\
NKX 2207 & $\ldots$ & $1,946.8 \mathrm{bc}$ & $\ldots$ \\
NKX 2907 & $\ldots$ & $1,909.6 \mathrm{c}$ & $\ldots$ \\
\hline
\end{tabular}

${ }^{\mathrm{z}}$ Mean separations within columns by Student-Newman-Keul's multiple range test, $P \leq 0.05$. 
Table 4. Evaluation of cotton entries for resistance to cotton leaf crumple (CLCr) disease based upon visual rating of leaf symptoms and detection of viral DNA by squash or dot blot hybridization analyses

\begin{tabular}{|c|c|c|c|c|c|c|}
\hline \multirow[b]{2}{*}{ Variety } & \multicolumn{3}{|c|}{ CLCr leaf rating ${ }^{x}$} & \multicolumn{3}{|c|}{ CLCr hybridization rating } \\
\hline & 1999 & 2000 & 2001 & 1999y & $2000^{z}$ & $2001^{\mathrm{z}}$ \\
\hline AP 4103 & 3.1 & 3.6 & 3.7 & 1.8 & 36.5 & 19.5 \\
\hline AP 6101 & 2.5 & 3.0 & 3.6 & 1.9 & 24.2 & 21.4 \\
\hline NKX C429-93-2ct & $\ldots$ & 2.2 & $\ldots$ & $\ldots$ & 19.1 & $\ldots$ \\
\hline Texas 121 & 1.3 & 2.1 & 2.8 & 1.0 & 30.3 & 22.4 \\
\hline NK 2108SS (DG 2108) & 1.4 & 1.8 & 3.4 & 1.4 & 28.1 & 20.1 \\
\hline NK 2907 & $\ldots$ & 1.8 & $\ldots$ & $\ldots$ & 22.8 & $\ldots$ \\
\hline NKX 2207 & $\ldots$ & 1.8 & $\ldots$ & $\ldots$ & 14.9 & $\ldots$ \\
\hline NK 2165C (DG 2165) & 1.0 & 1.8 & $\ldots$ & 1.0 & 11.2 & $\ldots$ \\
\hline Stoneville 474 & 1.7 & 1.2 & 2.6 & 1.0 & 6.2 & 7.7 \\
\hline NK 2387C (DG 2387) & 1.0 & 1.0 & 1.2 & 1.0 & 1.8 & 2.7 \\
\hline DPX 1883 & $\ldots$ & $\ldots$ & 1.1 & $\ldots$ & $\ldots$ & 3.0 \\
\hline DG 2383 & 1.2 & $\ldots$ & $\ldots$ & 1.1 & $\ldots$ & $\ldots$ \\
\hline
\end{tabular}

${ }^{\mathrm{x}}$ Rating scale used was: $1=$ leaves smooth, few if any bumps or blisters; $2=$ leaves with some obvious blisters and crumpling, but on $<50 \%$ of the leaf surface; $3=$ leaves with obvious crumpling, blisters, and vein clearing on $>50 \%$ of the leaf surface, but with little or no epinasty; and $4=$ leaves with severe crumpling, blisters, epinasty, and distortion.

${ }^{\mathrm{y}}$ Results for squash blot hybridization analysis.

${ }^{\mathrm{z}}$ Results for dot blot hybridization analysis.
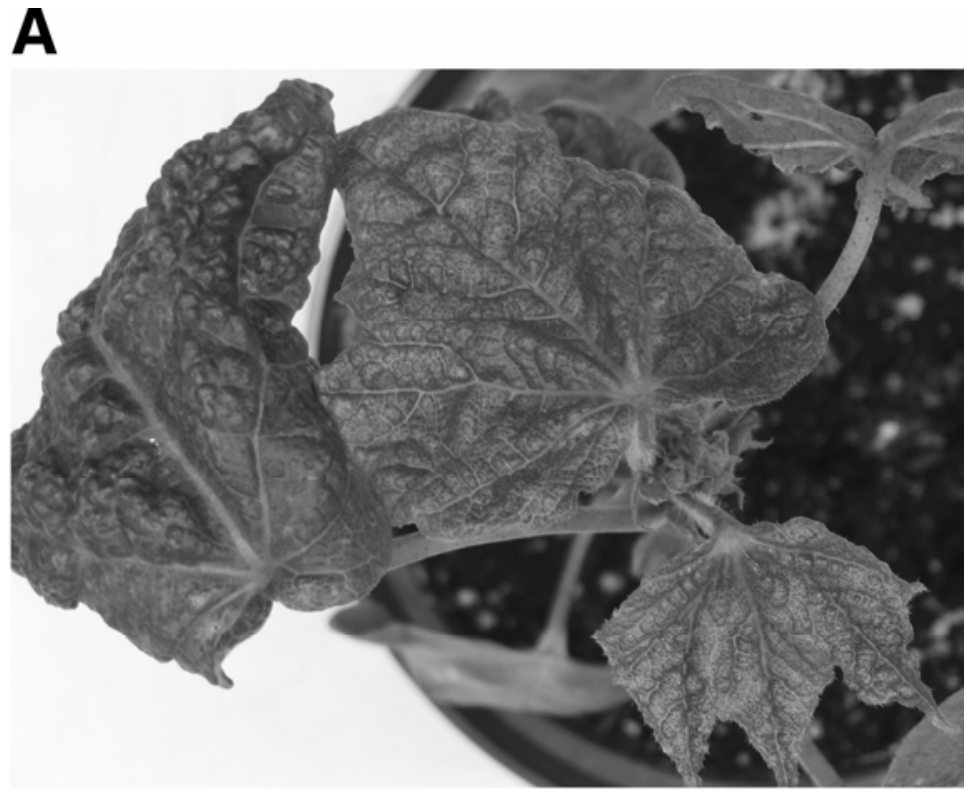

B

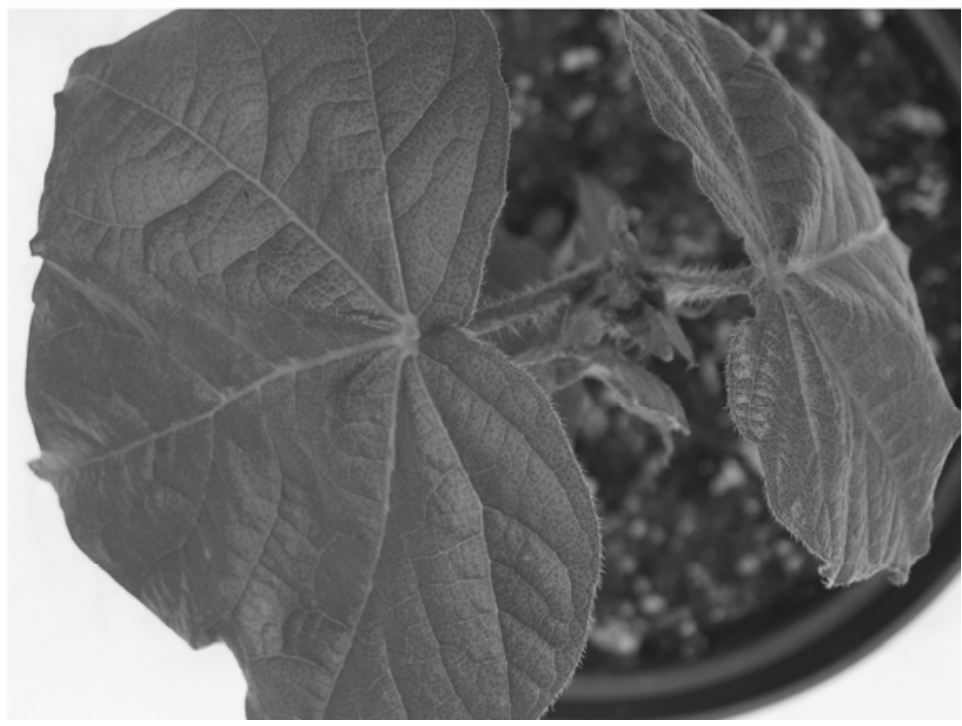

Fig. 1. Disease symptoms observed in cotton plants 21 days after particle bombardment inoculation with A, cloned DNA-A and DNA-B components of an isolate of Cotton leaf crumple virus from the Imperial Valley of California (CLCrV-CA) or B, gold particles only. whereas it was detected in some or all leaves of all other entries (data not shown). In 2001, AP 4103, AP 6101, and NK 2108SS had the highest DSRs (3.7, 3.6, and 3.4 , respectively) and high dot blot signals (19.5, 21.4, and 20.1, respectively). Texas 121 and Stoneville 474 had lower DSRs (2.6 and 2.8, respectively), but different dot blot signals (22.4 and 7.7, respectively). Although Stoneville 474 had a higher DSR in 2001 (2.1) compared with 2000 (1.2), it had a relatively low dot blot signal in both years (6.2 and 7.7). NK $2387 \mathrm{C}$ and a new entry, DPX 1883, had the lowest DSRs (1.2 and 1.1, respectively) and dot blot signals (2.7 and 3.0, respectively). In PCR tests, viral DNA was not detected in leaves of NK 2387 C or DPX 1883 , whereas it was detected in some or all leaves of the other entries (data not shown).

Etiology of CLCr disease in the Imperial Valley: Detection, characterization, and cloning of DNA components of a bipartite cotton begomovirus. Using PCR and degenerate primers, DNA-A $(\sim 1.1 \mathrm{~kb})$ and DNA-B $(\sim 1.5 \mathrm{~kb})$ fragments were consistently amplified from DNA extracts prepared from cotton leaves showing CLCr symptoms collected during the 1997 to 2002 growing seasons (data not shown). No fragments were amplified from equivalent extracts prepared from leaves of cotton plants with no symptoms. Representative PCR-amplified DNA-A and DNA-B fragments were cloned, and sequence analyses indicated that they represented components of a novel bipartite begomovirus (note that when these comparisons were made, no CLCrV sequences were available in the GenBank). These results indicated: (i) the DNA obtained from infected cotton leaf tissue by the CTAB method was suitable for PCR amplification of begomovirus DNA, and (ii) the association of a bipartite begomovirus with CLCr in the Imperial Valley.

When used in the PCR with a DNA extract prepared from symptomatic cotton leaves collected in the Imperial Valley in 2002, the DNA-A and DNA-B overlapping primers each directed the amplification of the expected $\sim 2.6-\mathrm{kb}$ DNA fragments (data not shown). These fragments were digested with the appropriate restriction enzyme and cloned to generate recombinant plasmids having putative full-length DNA-A and DNA-B components of the bipartite cotton begomovirus.

Infectivity of the DNA-A and DNA-B clones of the bipartite cotton begomovirus from the Imperial Valley. Cotton seedlings (AP 6101 and AP 4103) bombarded with the putative full-length DNA$\mathrm{A}$ and DNA-B monomers, released from recombinant plasmids pCLCrA1-40 and pCLCrB-8, respectively, developed CLCr symptoms (crumpling, blistering, and epinasty) in newly emerging leaves $\sim 10$ to 14 dpb (Fig. 1A). In five independent experi- 
ments, 16/20 AP 6101 and 10/31 AP 4103 seedlings developed CLCr symptoms, whereas seedlings bombarded with gold particles only did not develop symptoms (Fig. 1B). Begomovirus DNA-A and DNA$\mathrm{B}$ components were detected in leaves of representative symptomatic cotton plants by PCR, confirming that this bipartite cotton begomovirus can cause CLCr disease. In contrast, none of the 44 common bean (cv. Topcrop) seedlings bombarded with these full-length DNA-A and DNA-B monomers developed disease symptoms. Finally, in experiments performed with the highly resistant entries, none of the $\mathrm{NC}$ 2387C (0/88) or DPX 1883 (0/49) seedlings bombarded with the DNA-A and DNA-B monomers developed CLCr symptoms, whereas $40 \%$ (2/5) of bombarded AP 6101 seedlings did.

Whitefly transmission. All 10 cotton seedlings exposed to whiteflies provided a 24-h AAP on cotton plants infected after bombardment with the cloned DNAs of the bipartite cotton begomovirus developed CLCr symptoms, and begomovirus DNA$\mathrm{A}$ and DNA-B components were detected in representative plants by PCR. Six of 10 seedlings exposed to whiteflies provided a 24-h AAP on plants infected with the CLCrV field isolate developed CLCr symptoms, whereas no symptoms developed in seedlings exposed to whiteflies that were provided a 24-h AAP on symptomless cotton plants. Thus, progeny virus, derived from the cloned DNAs of the bipartite cotton begomovirus, is whiteflytransmissible.

Sequence analysis of infectious DNA$A$ and DNA-B clones of the bipartite cotton begomovirus from the Imperial Valley. The complete nt sequences of the DNA-A (in pCLCrA1-40) and DNA-B (in pCLCrB-8) components were determined.
The DNA-A component is 2,630 nt (GenBank accession no. AY742220), whereas the DNA-B component is 2,549 nt (GenBank accession no. AY742221). The DNA$\mathrm{A}$ and DNA-B sequences share a common region (CR) of $\sim 160 \mathrm{nt}$, which is $86 \%$ identical. This $\mathrm{CR}$ sequence contains the characteristic inverted repeat capable of forming a stem-loop structure; the highly conserved nanonucleotide sequence, TAATATTAC, within the loop sequence; and two copies of a virus-specific replication-associated (Rep) protein high-affinity binding site (GGAGT) (21; Fig. 2).

An analysis for open reading frames (ORFs or genes) encoding proteins $>10$ $\mathrm{kDa}$ revealed 4 ORFs for DNA-A, corresponding to the bipartite begomovirus AV1, AC1, AC2, and AC3; no AC4 ORF was detected. Two ORFs were detected for DNA-B, corresponding to the bipartite begomovirus BV1 and BC1. Comparisons made between sequences of the DNA-A and DNA-B components (total nt), individual ORFs (nt and amino acid [aa]), and CR (nt) with those of other begomoviruses revealed a high level of sequence identity ( $>97 \%$ at the nt level and $>96 \%$ at the aa level) with CLCrV-SON (23). The highest identities with other begomovirus species were 80 and $64 \%$ for total DNA-A and DNA-B sequences; 87 and $80 \%$ for individual DNA-A and DNA-B ORFs, respectively; and $60 \%$ for $\mathrm{CR}$ sequences (data not shown). Together, these results indicate that the bipartite cotton begomovirus from the Imperial Valley of California is an isolate of CLCrV (CLCrV-CA).

Comparisons performed with DNA-A sequences indicated that CLCrV-CA (and CLCrV-SON) is most similar to members of the Abutilon mosaic virus (AbMV) and Squash leaf curl virus (SLCV) groups of Western Hemisphere bipartite begomovi- ruses (data not shown). A phylogenetic analysis performed with the CLCrV-CA $\mathrm{AC} 1 \mathrm{nt}$ sequence placed $\mathrm{CLCrV}$ in the SLCV clade (Fig. 3A). DNA-B sequence comparisons also indicated that CLCrVCA (and CLCrV-SON) is most similar to members of the AbMV and SLCV groups (data not shown). However, a phylogenetic analysis performed with the BC1 ORF nt sequence placed CLCrV into the AbMV clade (Fig. 3B).

\section{DISCUSSION}

Leaf crumple of cotton was the first whitefly-transmitted disease with a suspected geminivirus etiology reported from southern California. Although CLCr has been a disease of relatively minor economic importance, increases in whitefly populations in the southwestern United States have raised concerns that whiteflytransmitted geminivirus diseases could emerge as significant constraints on crop production $(20,34)$. Identification of whitefly- or CLCr-resistant cotton entries, and development of molecular tools for screening for resistance, could help minimize the impact of CLCr, were it to emerge as an economically important disease.

Significant differences in densities of whitefly adults and nymphs were detected among cotton entries, but none were considered highly resistant to whitefly colonization. Moreover, AP 6101 and AP 4103, which had some of the lowest whitefly densities, consistently had the highest CLCr disease ratings. This indicates that these densities were sufficient to result in high levels of viral infection, which is consistent with the notion that begomoviruses can be efficiently spread by low densities of adult whiteflies.

A number of entries had moderate to high levels of CLCr resistance. In particu-
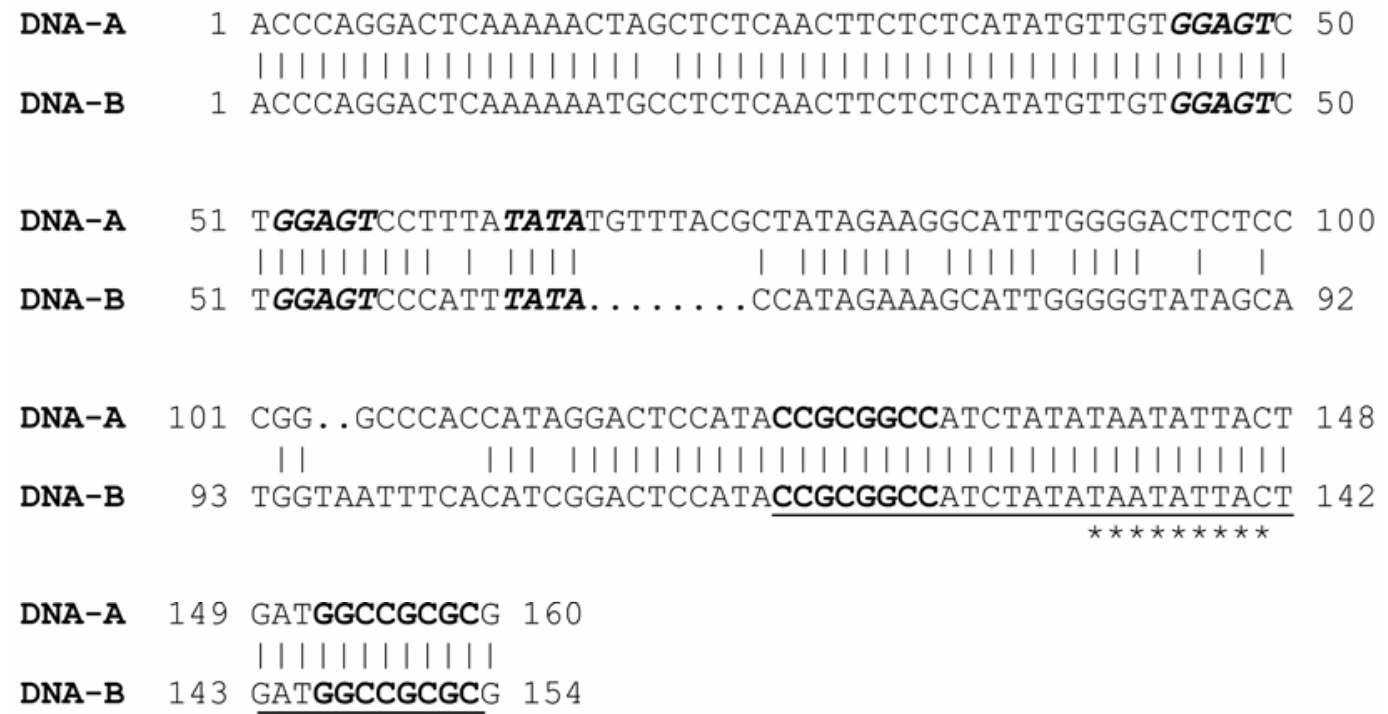

Fig. 2. Alignment of nucleotide sequences of common region nucleotide sequences of the infectious cloned DNA-A and DNA-B components of an isolate of Cotton leaf crumple virus from the Imperial Valley of California (CLCrV-CA). The conserved geminivirus stem-loop is indicated, with the stem sequence shown by bold letters and the invariant nanonucleotide sequence in the loop by asterisks. The Replication-associated protein high-affinity binding sites and TATA box are indicated in bold italics. 
lar, NK 2387C and DPX 1883 were highly resistant to $\mathrm{CLCr}$, showing no obvious symptoms and having little or no detectable viral DNA titers (even when tested with the highly sensitive PCR technique). These results indicate a level of resistance that is bordering on immunity. Moreover, as these entries sustained whitefly population densities that were similar to those on entries highly susceptible to CLCr, the absence of CLCr disease symptoms must reflect bona fide viral resistance as opposed to vector nonpreference. Further support for this notion came from the finding that these entries also showed a high level of resistance when inoculated with the cloned DNA of CLCrV-CA by particle bombardment. Finally, although the CLCr disease pressure in this study was not sufficient to result in lint yield reduction in the highly susceptible entries (e.g., AP 4103 and AP 6101), the yield of these highly resistant entries was comparable with other entries (including a number of commercial varieties). Thus, these entries have potential for the development of CLCr-resistant varieties.
Most of the resistant entries identified in the present study were of cv. Cedix parentage (38). The cv. Cedix was first identified in breeding programs in Central America designed to select materials with resistance to viruses causing a CLCr-like disease (4). In a study of the inheritance of CLCr resistance in cv. Cedix, the asymptomatic phenotype was dominant, but apparently conditioned by more than one gene (37). Therefore, the highly CLCr-resistant NK 2387C and DPX 1883 entries could also be used in a breeding program to develop CLCr-resistant cotton cultivars. In addition, these entries should be tested for resistance to cotton leaf curl disease, which is caused by a complex of a monopartite begomovirus species and satellite DNA molecules, and is of considerable economic importance in Pakistan, India, and northeast Africa $(3,25)$.

Several lines of evidence have implicated a whitefly-transmitted geminivirus as the causal agent of CLCr disease $(4,6,23-$ 25,29,35). The finding that typical CLCr disease symptoms developed in cotton seedlings inoculated with the cloned infec- tious DNA components of CLCrV-CA, together with the detection of the DNA-A and DNA-B components in these seedlings by PCR, indicates that this bipartite begomovirus is the cause of the disease in the Imperial Valley of California and represents the equivalent of Koch's postulates for this isolate. The transmission of progeny virus of CLCrV-CA by B. tabaci is consistent with this whitefly being the vector of CLCr disease in the Imperial Valley (24). These findings are also in agreement with those of Idris and Brown (23) for CLCrV-SON.

Idris and Brown (23) confirmed that CLCrV is a genetically distinct bipartite begomovirus species, and the high level of nt sequence identity $(>97 \%)$ between CLCrV-SON and CLCrV-CA indicates that these are isolates of a single begomovirus species. However, there are some notable differences between CLCrV-SON and CLCrV-CA. First, the predicted CR of the CLCrV-CA DNA-A and DNA-B components differed from that of CLCrV-SON components in having (i) an additional 8 nts at the $5^{\prime}$ end, (ii) a true TATA box in the
A

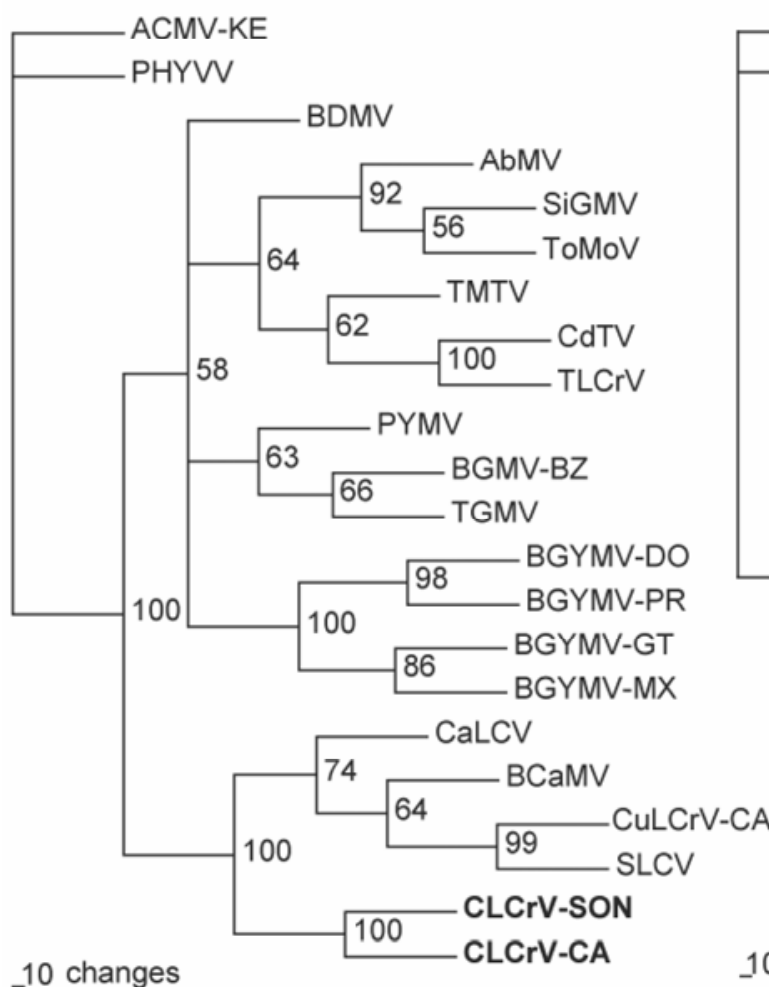

B

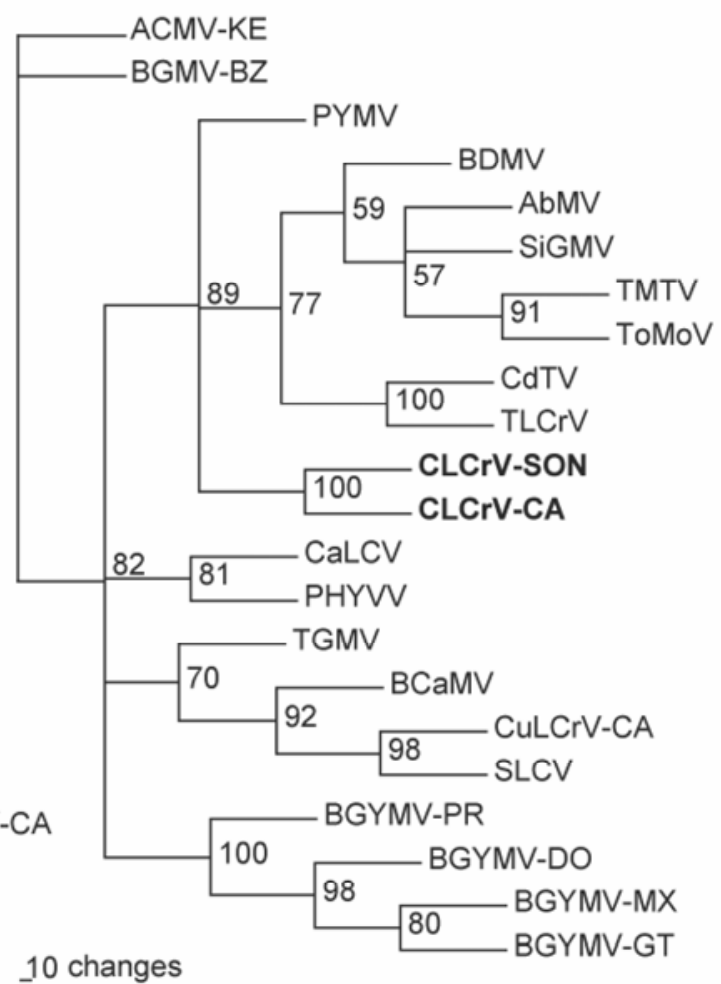

Fig. 3. Phylogenetic consensus trees showing the relationship of an isolate of Cotton leaf crumple virus from the Imperial Valley of California (CLCrV-CA) with other bipartite begomoviruses based on alignments of $\mathbf{A}$, the AC1 open reading frame (ORF) and $\mathbf{B}$, the BC1 ORF nucleotide sequences. Phylogenetic analyses were performed with PAUP (Phylogenetic Analysis Using Parsimony) version 4.0 b10 using heuristic search. Branch strengths were evaluated by constructing 100 trees in bootstrap analysis by step-wise addition at random. Bootstrap values $(>50 \%)$ are shown above the horizontal line. Horizontal lines are in proportion to the number of nucleotide differences between branch nodes. AbMV = Abutilon mosaic virus; ACMV-KE = African cassava mosaic virus from Kenya; BCaMV = Bean calico mosaic virus; BDMV = Bean dwarf mosaic virus; BGMV-BZ = Bean golden mosaic virus from Brazil; BGYMV-DO = Bean golden yellow mosaic virus from Dominican Republic; BGYMV-GT = BGYMV from Guatemala; BGYMV-MX = BGYMV from Mexico; BGYMV$\mathrm{PR}=\mathrm{BGYMV}$ from Puerto Rico; CaLCV = Cabbage leaf curl virus; CdTV = Chino del tomato virus; CLCrV-SON = Cotton leaf crumple virus from Sonora, Mexico; CuLCrV-CA = Cucurbit leaf crumple virus from California; PYMV = Potato yellow mosaic virus; $\mathrm{PHYVV}=$ Pepper huasteco yellow vein virus; SiGMV = Sida golden mosaic virus; SLCV = Squash leaf curl virus; TGMV = Tomato golden mosaic virus; TLCrV = tomato leaf crumple strain of CdTV; ToMoV = Tomato mottle virus from Florida; TMTV = Tomato mottle Taino virus from Cuba. CLCrV isolates are shown in bold letters. 
CR sequences of both components, and (iii) a higher level of sequence identity ( 86 versus $77 \%$ ) (23; Fig. 2). Second, common bean seedlings bombarded with the cloned CLCrV-CA DNA components did not develop disease symptoms, whereas those bombarded with the cloned CLCrV-SON DNA components did. This later finding may reflect either an actual biological difference between these viruses, a difference in the constructs used (monomers for CLCrV-CA versus tandem repeats for CLCrV-SON), or a difference in the common bean cultivars inoculated (cv. Topcrop for CLCrV-CA and cv. Red Kidney for CLCrV-SON). Further study is needed to resolve the nature of the differential pathogenicity of CLCrV in common bean.

The finding that sequences of PCRamplified DNA-A fragments from cotton plants with CLCr symptoms collected from the Imperial Valley in 1997, 1999, and 2002 were $>95 \%$ identical (data not shown), together with similar findings by Idris and Brown (23) for field isolates from other areas (Sonora, Mexico and Arizona, U.S.A.), indicates that CLCrV is the causal agent of this disease throughout the southeastern United States and northern Mexico. Although genetic variability in the virus(es) causing CLCr was previously suggested based on the identification of mild and severe strains in the Imperial and Coachella valleys (14), our results and those of Idris and Brown (23) did not reveal high levels of variability among CLCrV isolates associated with the disease in different geographical regions.

Results of sequence and phylogenetic analyses suggested a role for pseudorecombination and/or recombination in the evolution of CLCrV-CA. First, the CR of CLCrV-CA DNA components had a relatively lower sequence identity $(86 \%)$ and more gaps and divergent regions (Fig. 2) than CRs of most bipartite begomovirus species, which tend to have identities of $>90 \%$ and few gaps/divergent regions. These properties of the CLCrV-CA CR are reminiscent of those of infectious pseudorecombinants formed between the DNA components of the begomovirus species Bean dwarf mosaic virus and Tomato mottle virus (22). Second, the phylogenic analyses of the AC1 and BC1 ORFs placed CLCrVCA into two different phylogenetic branches of Western Hemisphere whiteflytransmitted begomoviruses (SLCV and $\mathrm{AbMV}$, respectively; Fig. 3A and B). Although phylogenetic analysis of the CLCrVSON DNA-B component, which was performed with the full sequence, did not place the virus into the AbMV clade, this may be due to the intermolecular recombination detected within this component (23). However, our results and those of Idris and Brown support the hypothesis that CLCrV originated as a pseudorecombinant, possibly composed of components of begomoviruses adapted to different host plants (23).
The CLCrV-CA clones and their sequences can be used to facilitate detection of $\mathrm{CLCrV}$ and for screening cotton entries for CLCr resistance. The dot blot method, using cloned CLCrV DNA as a probe, allowed for an assessment of viral titer in cotton germ plasm, and this was positively correlated with disease resistance. The infectious clones also can be used to develop vector-independent germ plasm screening methods, such as agroinoculation (17). Together with the identification of highly CLCr-resistant cotton, tools are now available that should allow for effective management of CLCr.

\section{ACKNOWLEDGMENTS}

This project was supported by grants from the University of California Center for Pest Management Research and Extension, Syngenta Seeds Inc., and Delta and Pine Land Company. We thank AgriPro Seeds, Delta and Pine Land Company, Stoneville Pedigree Seed Company, South Texas Planting Seed Assoc., and Syngenta Seeds Inc. for providing cotton entries; William Wintermantel and Art Perez for conducting whitefly transmission experiments; and Duncan Henry and Karina Perez for technical assistance.

\section{LITERATURE CITED}

1. Allen, R. M., Tucker, H., and Nelson, R. A. 1960. Leaf crumple disease of cotton in Arizona. Plant Dis. Rep. 44:246-250.

2. Bellows, T. S., Jr., Perring, T. M., Gill, R. J., and Headrick, D. H. 1994. Description of a species of Bemisia (Homoptera: Aleyrodidae). Ann. Entomol. Soc. Am. 81:195-206.

3. Briddon, R. W. 2003. Cotton leaf curl disease, a multicomponent begomovirus complex. Mol. Plant Pathol. 4:427-434.

4. Brown, J. K. 1992. Virus diseases. Pages 275330 in: Cotton Diseases. R. J. Hillocks, ed. C.A.B. International, Wallingford, UK.

5. Brown, J. K., Mihail, J. D., and Nelson, M. R. 1987. Effects of cotton leaf crumple virus on cotton inoculated at different growth stages. Plant Dis. 71:699-703.

6. Brown, J. K., and Nelson, M. R. 1984. Geminate particles associated with cotton leaf crumple disease in Arizona. Phytopathology 74:987-990.

7. Brown, J. K., and Nelson, M. R. 1987. Host range and vector relationship of cotton leaf crumple virus. Plant Dis. 71:522-524.

8. Butler, G. D., Jr., Brown, J. K., and Henneberry, T. J. 1986. Effect of cotton seedling infection by cotton leaf crumple virus on subsequent growth and yield. J. Econ. Entomol. 79:208-211.

9. Butler, G. D., Jr., Wilson, F. D., and Henneberry, T. J. 1985. Cotton leaf crumple virus disease in okra-leaf and normal-leaf cottons. J. Econ. Entomol. 78:1500-1502.

10. Cook, O. F. 1924. Acromania or 'crazytop', a growth disorder of cotton. J. Agric. Res. 28:803-828.

11. Dellaporta, S. L., Wood, J., and Hicks, J. B. 1983. A plant DNA minipreparation: Version II. Plant Mol. Biol. Rep. 1:19-21.

12. Dickson, R. C., Johnson, M. M., and Laird, E. F. 1954. Leaf crumple, a virus disease of cotton. Phytopathology 44:479-480.

13. Duffus, J. E., and Flock, R. A. 1982. Whitefly transmitted disease complex of the desert southwest. Calif. Agric. 36:4-6.

14. Erwin, D. C., and Meyer, R. 1961. Symptomatology of the leaf-crumple disease in several species and varieties of Gossypium and variation of the causal virus. Phytopathology 51:472-477.

15. Faria, J. C., Gilbertson, R. L., Hanson, S. F.,
Morales, F. J., Ahlquist, P., Loniello, A. O., and Maxwell, D. P. 1994. Bean golden mosaic geminivirus type II isolates from the Dominican Republic and Guatemala: Nucleotide sequences, infectious pseudorecombinants, and phylogenetic relationships. Phytopathology 84:321-329.

16. Garrido-Ramirez, E. R., and Gilbertson, R. L. 1998. First report of tomato mottle geminivirus infecting tomatoes in Yucatan, Mexico. Plant Dis. 82:592.

17. Garrido-Ramirez, E. R., Sudarshana, M. R., and Gilbertson, R. L. 2000. Bean golden yellow mosaic virus from Chiapas, Mexico: Characterization, pseudorecombination with other bean-infecting geminiviruses and germ plasm screening. Phytopathology 90:1224-1232.

18. Gawel, N. J., and Jarret, R. L. 1991. A modified CTAB DNA extraction procedure for Musa and Ipomoea. Plant Mol. Biol. Rep. 9:262-266.

19. Gilbertson, R. L., Hidayat, S. H., Martinez, R. T., Leong, S. A., Faria, J. C., Morales, F., and Maxwell, D. P. 1991. Differentiation of beaninfecting geminiviruses by nucleic acid hybridization probes and aspects of bean golden mosaic in Brazil. Plant Dis. 75:336-342.

20. Gilbertson, R. L., Ullman, D. E., Salati, R., Maxwell, D. P., Grafton-Cardwell, E. E., and Polek, M. 1998. Insect-transmitted viruses threaten agriculture. Calif. Agric. 52:23-28.

21. Hanley-Bowdoin, L., Settage, S. B., Orozco, B. M., Nagar, S., and Robertson, D. 1999. Geminiviruses: Models for plant DNA replication, transcription, and cell cycle regulation. Crit. Rev. Plant Sci. 18:71-106.

22. Hou, Y.-M., and Gilbertson, R. L. 1996. Increased pathogenicity in a pseudorecombinant bipartite geminivirus correlates with intermolecular recombination. J. Virol. 70:5430-5436.

23. Idris, A. M., and Brown, J. K. 2004. Cotton leaf crumple virus is a distinct Western Hemisphere begomovirus species with complex evolutionary relationships indicative of recombination and reassortment. Phytopathology 94:1068-1074.

24. Laird, E. F., and Dickson, R. C. 1959. Insect transmission of leaf crumple virus of cotton Phytopathology 49:324-327.

25. Nadeem, A., Weng, Z., Nelson, M. R., and Xiong, Z. 1997. Cotton leaf crumple virus and cotton leaf curl virus are distantly related geminiviruses. Mol. Plant Pathol. Online publication no. 1997/0612nadeem.

26. Naranjo, S. E., and Flint, H. M. 1995. Spatial distribution of adult Bemisia tabaci (Homoptera: Aleyrodidae) in cotton and development and validation of fixed-precision sampling plans for estimating population density. Environ. Entomol. 24:261-270.

27. Natwick, E. T. 1993. Silverleaf whitefly control in cotton using various insecticides in the Imperial Valley of California. D. J. Herber and D. A. Richter, eds. Proc.-Beltwide Cotton Conferences, National Cotton Council, Memphis, TN. pp. 722-729.

28. Natwick, E. T., Chu, C. C., Perkins, H. H., Henneberry, T. J., and Cohen, A. C. 1995 Pima and upland cotton susceptibility to $B e$ misia argentifolii under desert conditions. Southwest. Entomol. 20:429-438.

29. Natwick, E. T., Cook, C. G., Gilbertson, R. L., and Seo, Y.-S. 2000. Resistance in upland cotton to the silverleaf whitefly transmitted cotton leaf crumple disease. Proc.-Beltwide Cotton Conferences, National Cotton Council, Memphis, TN. 1:164-176.

30. Paplomatas, E. J., Patel, V. P., Hou, Y.-M., Noueiry, A. O., and Gilbertson, R. L. 1994. Molecular characterization of a new saptransmissible bipartite genome geminivirus infecting tomatoes in Mexico. Phytopathology 84:1215-1224.

31. Patel, V. P., Rojas, M. R., Paplomatas, E. J., and Gilbertson, R. L. 1993. Cloning biologi- 
cally active geminivirus DNA using PCR and overlapping primers. Nucleic Acids Res. 21:1325-1326.

32. Perring, T. M., Cooper, A. D., Kazmer, D. J., Shields, C., and Shields, J. 1991. New strain of sweetpotato whitefly invades California vegetables. Calif. Agric. 45:10-12.

33. Rojas, M. R., Gilbertson, R. L., Russell, D. R., and Maxwell, D. P. 1993. Use of degenerate primers in the polymerase chain reaction to de- tect whitefly-transmitted geminiviruses. Plant Dis. 77:340-347.

34. Toscano, N. C., Castle, S. J., Henneberry, T. J., and Prabhaker Castle, N. 1998. Persistent silverleaf whitefly exploits desert crop systems. Calif. Agric. 52:29-33.

35. Tsao, P. W. 1963. Intranuclear inclusion bodies in the leaves of cotton plants infected with leaf crumple virus. Phytopathology 53:243-244.

36. Van Schaik, P. H., Erwin, D. C., and Garber,
M. J. 1962. Effects of time and symptom expression of the leaf-crumple virus on yield and quality of fiber of cotton. Crop Sci. 2:275-277.

37. Wilson, E. D., and Brown, J. K. 1991. Inheritance of resistance to cotton leaf crumple virus in cotton. J. Hered. 82:508-509.

38. Wilson, F. D., Brown, J. K., and Butler, G. D., Jr. 1989. Reaction of cotton cultivars and lines to cotton leaf crumple virus. AZ-NV Acad. Sci. 23:7-10. 